\title{
PENGARUH LATIHAN SPRINT DAN BOX SKIP TERHADAP KEMAMPUAN LOMPAT JAUH PADA PUSAT PELATIHAN ATLETIK JUNIOR MUARO JAMBI
}

\author{
Palmizal \\ Fakultas Ilmu Keolahragaan, Universitas Jambi \\ palmizal @unja.ac.id
}

\begin{abstract}
Abstrak : Berdasarkan pengamatan penulis di pusat pelatihan atletik junior Muaro Jambi, saat materi lompat jauh atlet melakukan lompatan masih kurangnya kekuatan otot tungkai dan kecepatan sprint. Atlet yang melakukan lompatan kurang mampu untuk mencapai hasil yang maksimal. Tujuan penelitian ini adalah untuk melihat pengaruh latihan Sprint dan Box Skip terhadap kemampuan lompat jauh pusat pelatihan atletik junior Muaro Jambi. Penelitian dilakukan 3 kali seminggu dengan frekuensi latihan 16 kali pertemuan. Penelitian ini dilakukan di lapangan lompat jauh pusat pelatihan atletik junior Muaro Jambi. Metode yang digunakan pada penelitian ini adalah metode eksperimen yang menggunakan uji hipotesis yaitu Uji-T. dengan jumlah sampel 27 siswa dengan teknik pengambilan sampel yaitu dengan cara total sampling. Hasil Penelitian Berdasarkan uji hipotesis yang dilakukan terhadap tes awal dan tes akhir kemampuan lompat jauh dalam analisis data yang mengunakan uji-T di mana tes awal diperoleh rata-rata 3,85 poin dan tes akhir diperoleh rata-rata 4,49 poin. Sedangkan Thitung sebesar 7,53774 bila di bandingkan dengan Ttabel sebesar 1,70562 dengan ini sudah jelas ada peningkatan di sebabkan tes awal dan tes akhir mempunyai hasil yang berbeda. Berdasarkan hasil penelitian dan pembahasan yang telah dilakukan, maka dapat dipahami bahwa Latihan Sprint dan Box Skip memberikan pengaruh terhadap peningkatan kemampuan lompat jauh pada pusat pelatihan atletik junior Muaro Jambi.
\end{abstract}

Kata Kunci : Sprint dan Box Skip, Kemampuan Lompat Jauh

\section{PENDAHULUAN}

Olahraga merupakan bagian dari aktivitas sehari-hari yang sangat penting dan sudah dijadikan kebutuhan bagi manusia dan berguna untuk membentuk jasmani dan rohani yang sehat. Hal ini terbukti bahwa sepadat apapun kegiatan yang dilakukan masih disempatkan untuk melakukan kegiatan olahraga. Perkembangan olahraga sampai saat ini telah memberikan kontribusi yang sangat positif dan sangat nyata bagi peningkatan kebugaran, kesegaran dan kesehatan masyarakat. Di samping itu olahraga turut berperan besar bagi peningkatan prestasi baik di Nasional maupun di Internasional.

Atletik adalah suatu cabang olahraga yang terdiri dari 3 nomor perlombaan, yaitu: nomor jalan dan lari, lompat dan lempar. Salah satu nomor dalam atletik adalah lompat jauh, nomor ini termasuk yang favorit dan banyak digemari oleh pecinta atletik. Dalam lompat jauh terdapat unsur yang sangat dominan dan sangat mempengaruhi hasil lompatan yaitu kecepatan saat melakukan awalan dan kekuatan saat melakukan tolakan. Apabila kedua ini bisa dilakukan dengan baik maka akan mendapatkan hasil yang maksimal dalam lompatan.

Berdasarkan pengamatan penulis di pusat pelatihan atletik junior Muaro Jambi, saat latihan nomor lompat jauh saat atlet melakukan lompat jauh masih kurangnya memiliki kekuatan otot tungkai dan kecepatan sehingga hasil yang didapat tidak maksimal untuk mengatasi permasalahan yang dihadapi oleh atlet, maka akan diberikan latihan sprint dan box skip untuk guna meningkatkan kekatan otot kaki dan kecepatan lari pada pusat pelatihan atletik junior Muaro Jambi. Dengan harapan setelah melakukan latihan sprint dan box skip diharapkan nantinya kemampuan lompat jauh atlet akan menjadi lebih baik dan mencapai hasil yang maksimal dalam proses latihan.

Berdasarkan uraian di atas, maka penulis tertarik untuk mengadakan penelitian yang berjudul "Pengaruh Latihan sprint dan box skip Terhadap kemampuan Lompat Jauh Pada pusat pelatihan atletik junior Muaro Jambi."

\section{Hakekat Atletik}

Istilah atletik berasal dari bahasa Yunani yaitu "Atletik" yang memiliki makna bertanding atau berlomba. Istilah atletik yang digunakan di Indonesia saat ini diambil dari bahasa inggris yaitu atletik yang berarti cabang olahraga yang meliputi jalan, lari, lompat, dan lempar. Sementara di Amerika Serikat, istilah atletik berarti olahraga pertandingan, dan 
istilah menyebut atletik adalah track and field (Winendra, 2008:4)

Menurut Yudha, (2001:2) bahwa atletik merupakan kegiatan manusia sehari-hari yang dapat dikembangkan menjadi kegiatan bermain dan berolahraga yang diperlombakan dalam bentuk jalan, lari, lompat dan lempar.sedangkan menurut Winendra, (2008:4) atletik adalah sekumpulan olahraga yang meliputi lari, jalan, lempar, dan lompat, yang telah menjadi aktivitas olahraga tertua dalam peradapan manusia.

Jalan, lari, lompat dan lempar adalah bentuk kegiatan yang tidak ternilai artinya bagi manusia. Semua gerakan ini termasuk dalam atletik, bahkan gerakan tersebut merupakan esensi dari semua cabang olahraga. Tentu saja, penguasaan teknik dalam jalan, lari, lompat, dan lempar pada waktu itu masih sangat sederhana. Demikian pula keadaan alatalat dan fasilitas yang dipakai. Keadaan ini, tentu sangat berbeda dengan perkembangan atletik modern yang dikelola dengan memanfaatkan ilmu dan teknologi.

Atletik merupakan sarana untuk pendidikan jasmani dalam upaya meningkatkan daya tahan, kekuatan, kecepatan dan kelincahan dan lain sebagainya, selain untuk sarana pendidikan juga sebagai sarana penelitian bagi para ilmuan (Djumidar, 2001:13)

\section{Lompat Jauh}

Lompat jauh adalah suatu aktivitas dalam atletik dengan gerakan yang dilakukan di dalam lompatan untuk mencapai lompatan yang sejauhjauhnya. Gerakan lommpat jauh memperpadukan kecepatan, kekuatan, kelenturan, daya tahan dan ketepatan. (Aminudin, 2010: 17) Lompat jauh merupakan salah satu nomor yang dipertandingkan pada cabang olahraga atletik. Di sekolah-sekolah olahraga ini telah menjadi bagian materi dari kurikulum pendidikan jasmani yang harus dipelajari. Tujuan dari lompat jauh adalah melompat sejauhjauhnya dengan tahapan awalan, tolakan, melayang dan mendarat. (Djumidar, 2008:13)

Landasan lari untuk lompat ialah jarak tempuh pelompat dari awal sampai ke balok tumpuan 45 $\mathrm{m}$,dan lebar nya 1,22 $\mathrm{m}$ serta harus bersih dari benda keras dan benda tajam.

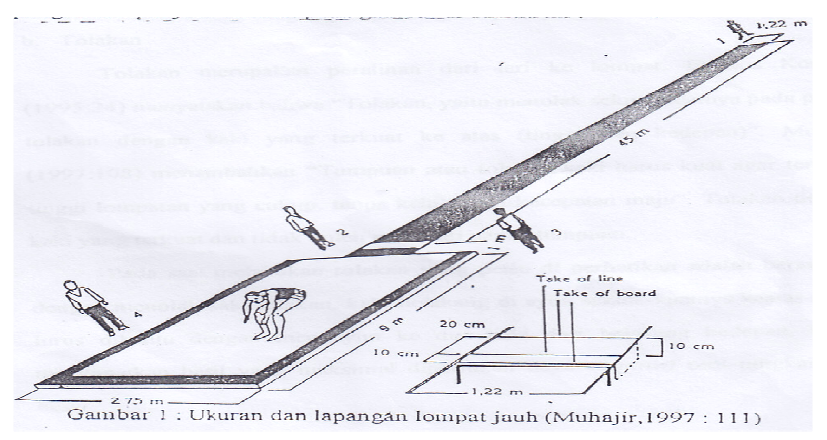

Gambar 1. Ukuran Lapangan Lompat Jauh (Muhajir, 2007:111)

\section{Teknik Lompat Jauh}

Secara teknik lompat jauh gaya jongkok ada empat unsur yang terdiri dari : awalan, tolakan, sikap badan di udara, serta mendarat. Pada dasarnya keempat unsur itu tidak dapat dipisahkan satu persatu karena gerakan nya adalah gerakan yang membentuk rangkaiaan gerak lompat jauh yang tidak terputus. Disamping itu di pengaruhi oleh kecapatan awalan, kekuatan tungkai tumpu, koordinasi sewaktu melayang di udara dan mendarat. (Bellesteros, 1979:53).

Awalan Guna awalan atau ancang - ancang adalah untuk mendapat kecepatan yang setinggi-tinggi nya sebelum mencapai balok tolakan, seorang yang ingin mencapai hasil yang baik dalam lompatan di tuntut suatu lari dari awalan yang cepat dengan langkah- langkah yang tetap supaya dapat bertumpuh pada balok tumpuan dengan cepat. (Dikdik, 2010:66).

Tolakan Tolakan merupakan peralihan dari lari ke lompat yaitu menolak sekuat-kuatnya pada papan tolakan dengan kaki ke atas (tinggi ke depan) tumpuan atau tolakan kaki harus kuat agar tercapai tinggi lompatan yang cukup, tanpa kehilangan kecepatan maju. Tolakan kaki yang terkuat tidak boleh melewati papan tumpuan. Pencapaian kaki adalah aktif dan cepat dengan suatu gerakan kebawa dan kebelakang. Waktu bertolak dipersingkat, pembengkokkan minimum dari kaki penumpu. Paha tungkai bebas didorong ke posisi horizontal dan sendi-sendi pergelangan kaki, lutut dan pinggang diluruskan sepenuhnya. (Dikdik, 2010:66) 


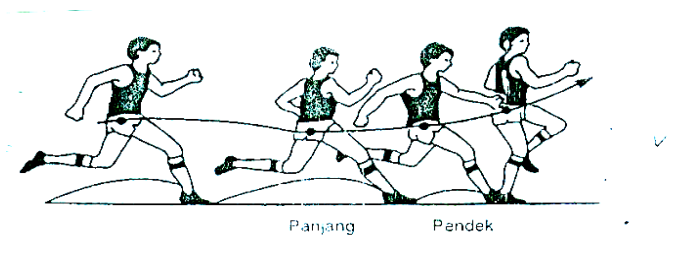

Gambar 2. Melakukan Tolakan (Carr, 2000:154)

Melayang di Udara Melayang di udara juga sangat penting karena mempengaruhi jauh nya lompatan seseorang. Sesudah bertolak, tariklah kaki bebas ke bawah dan kebelakang, pada saat yang sama, tariklah kaki yang bertolak kedepan dan ke atas. (Muhajir, 2007:49)

Mendarat Mendarat harus sedemikian rupa sehingga kaki yang diancangkan ke depan tidak menyebabkan bahwa pelompat akan mendarat dengan pantatnya. Tariklah lengan dan tubuh kedepan-bawah dan kebelakang. Luruskan kaki dan tekuk lagi sedikit sesaat sebelum menyentuh pasir. Kemudian bila kaki telah mendarat di pasir, duduklah atas kedua kaki. (Muhajir, 2007:49).

Mendarat Mendarat harus sedemikian rupa sehingga kaki yang diancangkan ke depan tidak menyebabkan bahwa pelompat akan mendarat dengan pantatnya. Tariklah lengan dan tubuh kedepan-bawah dan kebelakang. Luruskan kaki dan tekuk lagi sedikit sesaat sebelum menyentuh pasir. Kemudian bila kaki telah mendarat di pasir, duduklah atas kedua kaki. (Muhajir, 2007:49).

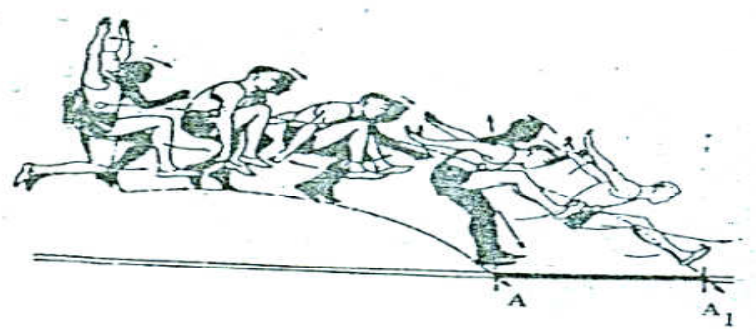

Gambar 3. Melayang Di Udara (Carr, 2000:154)

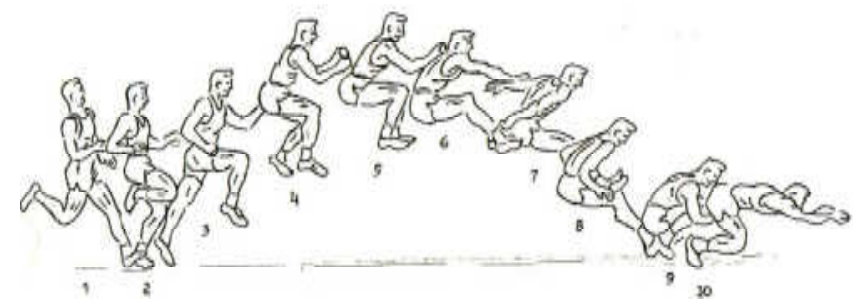

Gambar 4. Serangkaian Gerak Lompat Jauh Gaya Jongkok (Carr, 2000:153)

\section{Box Skip}

Box skip merupakan salah satu latihan plyometrik yang sering digunakan setiap pelatih karena latihan ini sangat mudah dilakukan dan simpel latihan ini juga bisa dilakukan di mana saja seperti lapangan, halaman rumah, di dalam gedung dan lain sebagainya, latihan box skip ini dapat meningkatkan kekuatan otot tungkai dengan cara meloncat dengan satu kaki ke atas kotak dengan cara bertahap kemudian meloncat lagi turun ke lantai dengan dua kaki (Bompa, 1984:35).

Box Skip merupakan latihan meloncat ke atas kotak atau balok kemudian meloncat turun kembali ke depan seperti sikap awal dengan menggunakan ke dua tungkai bersama-sama. Latihan ini bertujuan untuk meningkatkan kekuatan otot tungkai pada siswa atau atlet agar saat 
melakukan lompatan dapat maksimal. (Donald, 1992:48).

Box skip merupakan program latihan untuk meningkatkan kekuatan otot tungkai menggunakan alat, yaitu berupa sebuah kotak, dengan cara menggunakan tumpuan satu kaki secara bergantian kemudian melompat ke atas kotak lalu turun kembali dan melompat kembali ke kotak tersebut. (Kosasih, 1985: 46)

Berdasarkan pendapat di atas dapat di pahami bahwa box skip adalah salah satu latihan plyometrik yang sering digunakan untuk meningkatkan kekuatan otot tungkai dengan menggunakan alat berupa kotak. Latihan ini dilakukan dengan cara meloncat ke atas kotak atau balok kemudian meloncat turun kembali ke depan seperti sikap awal dengan menggunakan ke dua tungkai bersama-sama.

Gerakan latihan box skip pertama posisi badan menghadap ke kotak kemudian mengambil aba-aba siap untuk meloncat ke kotak atau balok, kaki agak ditekuk setelah sampai di atas kotak kemudian jongkok sedikit dan langsung meloncat, sedangkan kaki mendarat ketanah secara spontan. Lakukan gerakan di atas secara berulang-ulang.

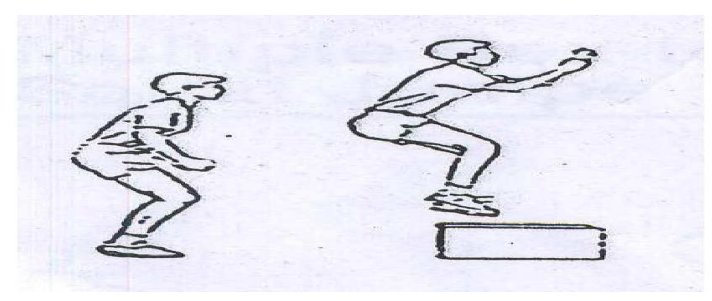

Gambar 5. Latihan Box Skip (A. Chu Donald, 1992:48)

Agar seseorang mampu melakukan lompat jauh yang baik, maka komponen otot kaki dan kecepatan lari haruslah baik serta kuat maka dari itu perlu dilatih dengan baik pula, dengan menambahkan suatu jenis latihan fisik yang terporgam dan continue, maka dapat erat kaitannya terhadap peningkatan jauhnya lompatan dengan metode latihan yang digunakan, yaitu latihan sprint dan jumping terhadap kemampuan lompat jauh pusat pelatihan atletik junior Muaro Jambi. Maka hipotesis dalam penelitian ini adalah : "Terdapat Pengaruh Latihan Sprint dan box skip Terhadap Kemampuan Lompat Jauh Pada pusat pelatihan atletik junior Muaro Jambi”.

\section{METODE}

Penelitian dilaksanakan di lapangan lompat jauh pusat pelatihan atletik junior Muaro Jambi. Penelitian ini dilakukan lebih kurang selama 6 minggu atau 16 kali pertemuan dengan frekuensi latihan 1 minggu 3 kali pertemuan.

Penelitian ini termasuk penelitian eksperimen karena tujuannya adalah untuk melihat akibat dari suatu perlakuan. Rancangan penelitian ini menggunakan rancangan one group pre testpost test design yaitu satu kelompok yang diberikan perlakuan terlebih dahulu diberi tes awal (pretest), kemudian diberi perlakuan dengan memberikan suatu jenis latihan (treatment), dan dilakukan tes akhir (post-test).

Pelaksanaan dari penelitian eksperimen ini dilakukan dengan cara memberikan program latihan kepada kelompok perlakuan yaitu dengan latihan yang terpogram dan continue.

\section{Populasi dan Sampel}

Populasi dalam penelitian ini adalah atlet pusat pelatihan atletik junior Muaro Jambi dengan jumlah populasi sebanyak 27 orang.

Sampel yang digunakan dalam penelitian ini adalah jumlah populasi atlet pusat pelatihan atletik junior Muaro Jambi sebanyak 27 atlet Putra dengan teknik pengambilan sampel total sampling. Variabel dalam penelitian ini ada dua yaitu variabel bebas dan variabel terikat. Variabel bebas (x) yaitu latihan sprint dan box skip, serta variabel terikat (y) yaitu kemampuan lompat Jauh.

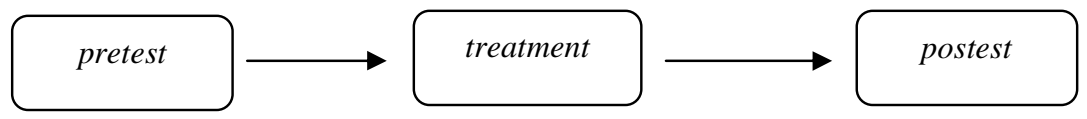

Gambar 6. Rancangan Penelitian

Keterangan:

Pre Test = tes awal lompat Jauh

Treatment $=$ perlakuan latihan Sprint dan box skip

Post Test $=$ tes akhir lompat Jauh 
Instrumen yang digunakan dalam penelitian ini adalah tes kemampuan lompat jauh, yang dimana tes tersebut dilakukan pada dua tahap yaitu tes awal dan tes akhir. Adapun Instrumen yang digunakan untuk memperoleh data pada siswa yang mengikuti tes ialah tes kemampuan lompat jauh.

Adapun alat yang digunakan dalam penelitian ini adalah lintasan lompat jauh, meteran, alat tulis buku dan pena

Teknik pengambilan data dilaksanakan dengan tes dan pengukuran, untuk memperoleh data yang objektif tentang hasil latihan atlet. Tes dan pengukuran dalam penelitian ini dilaksanakan untuk mendapatkan data hasil tentang kemampuan lompat jauh yang dilaksanakan dua kali yaitu pretest dan pos-test. Hasil tes dicatat dalam satuan angka.
Petunjuk pelaksanaan tes :

Uraian pelaksanaan tes dengan ketentuan sebagai berikut :

1. Tiap peserta di berikan kesempatan melompat sebanyak 3 kali

2. Hasil dari ketiga lompatan dicatat secara lengkap

3. Hasil yang diambil adalah hasil lompatan terjauh dari 3 kali kesempatan

4. Jarak lompatan diukur dari papan tolakan sampai jarak lompatan yang dihasilkan oleh bagian tubuh

5. Pada saat melakukan tolakan pelompat tidak boleh melewati papan tolakan jika melewati maka hasil lompatan tidak diambil. Sumber. (Carr, 2000:159)

Tabel 1. Norma Lompat Jauh (Carr, 2000:158)

\begin{tabular}{|c|c|c|}
\hline NO. & Jarak (Meteran) & Kriteria \\
\hline 1 & $>-4,95$ & Sangat Baik \\
\hline 2 & $4,63-4,94$ & Baik \\
\hline 3 & $4,49-4,62$ & Cukup \\
\hline 4 & $4,24-4,48$ & Kurang \\
\hline 5 & $<-4,23$ & Kurang Sekali \\
\hline
\end{tabular}

\section{Teknik Pengambilan dan Analisis Data}

Analisis data dilakukan untuk menguji hipotesis yang telah dirumuskan. Uji hipotesis yang digunakan adalah uji-t. Untuk melakukan uji-t populasi harus berdistribusi normal dan bervariasi homogen. Uji normalitas bertujuan untuk melihat apakah data berdistribusi normal atau tidak, digunakan uji liliefors yang dikemukakan oleh Sudjana,(2005:367) sebagai berikut:

a) Mencari skor baku dengan rumus,

$$
Z_{i}=\frac{X_{1-\bar{X}}}{S}
$$

Keterangan :

$$
\begin{array}{ll}
\mathrm{Z}_{\mathrm{i}} & =\text { Skor Baku } \\
\mathrm{X}_{\mathrm{i}} & =\text { Skor Hasil lompat Jauh } \\
\bar{X} & =\text { Rata-rata hasil lompat Jauh } \\
\mathrm{S} & =\text { Simpangan Baku }
\end{array}
$$

b) Untuk tiap bilangan baku ini, dan menggunakan daftar distribusi normal baku, kemudian dihitung peluang dengan rumus : $\mathrm{p}(\mathrm{z}<\mathrm{zi})$.

c) menghitung proporsi $Z^{1}, Z^{2}, \ldots \ldots . . . \mathrm{Zn}$ yang lebih kecil atau sama dengan $\mathrm{Zi}$. Jika proporsi ini dinyatakan $\mathrm{s}(\mathrm{Zi})$, maka :

$$
\mathrm{S}(\mathrm{zi})=\frac{\text { Banyaknya } Z 1, Z 2, \ldots \ldots . Z n \leq Z i}{n}
$$

Keterangan $: \mathrm{n}=$ Jumlah peserta

d) Menghitung selisih $F\left(Z_{i}\right)-S\left(Z_{i}\right)$ kemudian tentukan harga mutlaknya

e) Ambil harga yang paling besar sebutlah namanya $\mathrm{L}_{0}$.

f) Membandingkan $L_{0}$ dengan harga kritis $L$ dalam tabel dengan $\alpha=0,05$ Jika $\mathrm{L}_{0}<\mathrm{L}$ berarti hasil tes Lompat jauh berdistribusi normal dan sebaliknya Jika $L_{0}>L$ berarti skor hasil tes lompat jauh tidak berdistribusi normal.

\section{Uji Homogenitas Varians}

Uji ini digunakan untuk melihat apakah kedua kelompok pre-test dan post-test mempunyai varians homogen atau tidak. Dijelaskan rumus yang digunakan adalah sebagai berikut,

$$
f=\frac{S^{2}{ }_{1}}{S^{2}{ }_{1}}
$$

Keterangan :

$S_{1}^{2}$ : varians terbesar dari kemampuan lompat jauh $S_{2}^{2}$ : varians terkecil dari kemampuan lompat jauh 
Harga $f$ yang diperoleh dibandingkan dengan $f$

tabel (Fa $\left(\mathrm{V}_{1}, \mathrm{~V}_{2}\right)$

Dan $F^{1}-a\left(V_{1}-V_{2}\right)$ bila :

$F^{1}$-a $\left(V_{1}-V_{2}\right)<F_{\text {hitung }}<F^{1}-a\left(V_{1}-V_{2}\right)$ : varians nilai homogen

$F^{1}$-a $\left(V_{1}-V_{2}\right)>F_{\text {hitung }}>F^{1}-a\left(V_{1}-V_{2}\right)$ : varians nilai tidak homogen

\section{Uji Hipotesis (Uji T)}

Untuk menguji hipotesis digunakan uji statistik. Keamanan dua rata-rata yang bertujuan untuk menentukan apakah hasil yang diperoleh dari latihan jumping berpengaruh terhadap jauhnya lompatan menggunakan pre-test dan post-test one group design, maka pengujian hipotesis tersebut digunakan uji-t. Uji hipotesis menggunakan uji-t pada taraf kepercayaan $95 \%$ atau a $=0,05$ dengan menggunakan rumus suharsimi Arikunto (2010: 349) sebagai berikut :

$$
\mathrm{t}=\frac{\mathrm{Md}}{\sqrt{\frac{\sum x^{2} d}{n(n-1)}}}
$$

Keterangan :

$\begin{array}{ll}\mathrm{T} & =\text { jumlah } \mathrm{t} \text {-test yang dicari } \\ \mathrm{Md} & =\text { Mean dari perbedaan pre test dengan } \\ & \text { post test } \\ \mathrm{X}_{\mathrm{d}} & =\text { Deviasi masing-masing subjek }(\mathrm{d}-\mathrm{Md}) \\ \Sigma \mathrm{X}^{2} \mathrm{~d} & =\text { Jumlah kuadrat deviasi } \\ \mathrm{N} & =\text { Subjek pada sampel } \\ \mathrm{d} . \mathrm{b} & =\end{array}$

\section{HASIL DAN PEMBAHASAN}

Hasil penelitian ini akan digambarkan sesuai dengan tujuan dan hipotesis yang akan diajukan sebelumnya. Hasil pengukuran kemampuan lompat jauh pada atlet pusat pelatihan atletik junior Muaro Jambi dapat dilihat dan terangkum pada tabel sebagai berikut:

Dalam tes awal ini di dapat jumlah nilai keseluruhan kemampuan lompat jauh pada atlet pusat pelatihan atletik junior Muaro Jambi adalah 104,01 poin, dengan demikian dapat dirata-ratakan kemampuan lompat jauh pada atlet pusat pelatihan atletik junior Muaro Jambi adalah 3,85 poin maka hasil tes awal kemampuan lompat jauh dapat dikategorikan baik. Tes akhir penelitian ini yaitu tes yang dilakukan setelah atlet pusat pelatihan atletik junior Muaro Jambi tersebut diberi perlakuan atau di beri latihan, sehingga pada tes akhir ini merupakan tes setelah melakukan latihan Sprint dan Box Skip terhadap kemampuan lompat jauh. Pada tes akhir ini di dapat jumlah 121,27 poin. Dengan demikian rata-rata kemampuan lompat jauh pada atlet pusat pelatihan atletik junior Muaro Jambi adalah sebesar 4,49 Poin maka hasil tes akhir kemampuan lompat jauh dapat dikatagorikan baik.

Jika dilihat dari hasil kemampuan lompat jauh pada atlet pusat pelatihan atletik junior Muaro Jambi pada tes awal berjumlah 104,01 poin dibandingkan dengan hasil tes akhir kemampuan lompat jauh pada atlet pusat pelatihan atletik junior Muaro Jambi sebesar 121,27 poin terlihat tampak perbedaan diantara kedua hasil tersebut. Hal ini dapat dilakukan dengan membandingkan tes akhir dan tes awal terhadap thitung dalam taraf kepercayaan 0,05. Apabila thitung lebih besar dari ttabel ini berarti adanya perbedaan yang berarti dan sebaliknya apabila thitung lebih kecil dari ttabel ini berarti tidak adanya perbedaan yang berarti.

Analisis uji normalitas distribusi korvariabel dengan menggunakan Latihan Sprint dan Box Skip data pre-test dan post-test dianalisis dengan statistik uji normalitas liliefors dengan taraf signifikan yang digunakan sebagai dasar untuk menolak atau menerima keputusan normal atau tidaknya suatu distribusi data adalah $\alpha=0,05$. Membandingkan Lhitung dengan LTabel dengan menggunakan kriteria; jika Lhitung lebih besar dari Ltabel (Lo > Lt) berarti populasi berdistibusi tidak normal, sebaliknya jika Lhitung lebih kecil dari pada Ltabel (Lo < Lt) berarti populasi berdistribusi normal. Hasil data tes awal dan tes akhir Fhitung 1,17 < Ftabel 1,93 maka data dikatakan bersifat homogen.

Untuk menguji hipotesis dilakukan perbandingan antara thitung dengan nilai persentil dari distribusi untuk taraf nyata $\alpha=0,05$ dan derajat kebebasan $\mathrm{dk}=\mathrm{N}-1$ diperoleh thitung $=$ 7,53774 dan ttabel $=1,70562$ (Thitung > Ttabel) dalam penelitian ini dapat dipahami bahwa "ada pengaruh Latihan Sprint dan Box Skip Terhadap kemampuan lompat jauh pada atlet pusat pelatihan atletik junior Muaro Jambi. Hasil data hipotesis thitung 7,53774 > ttabel 1,70562 maka hasil uji hipotesis dapat diterima pada tingkat kepercayaan $95 \%$.

Dalam pelaksanaan penelitian ini, peneliti mengkaji tentang peningkatan pada sampel yang mulanya atlet pusat pelatihan atletik junior Muaro Jambi tersebut pada kemampuan lompat jauh masih kurang dan di bawah rata-rata dengan adanya perlakuan maka kemampuan lompat jauh pada sampel menjadi meningkat. Latihan sprint dan box skip dapat meningkatkan kemampuan lompat jauh, dari tes awal nilai tertinggi adalah sebesar 5,23 poin, dan yang paling rendah adalah sebesar 2,24 poin dengan rata-rata dari keseluruhan tes awal adalah 3,85 poin, selanjutnya pada tahap perlakuan (Treatment) pada sampel menggunakan latihan sprint dan box skip. 
Setelah tahap perlakuan (Treatment) ini selanjutnya ada tahap terakhir yaitu tes akhir (Postest). Hasil postest yaitu dengan nilai yang tertinggi adalah 5,65 poin dan yang terkecil yaitu 3,37 poin dan rata-rata dari tes akhir yaitu mengalami peningkatan 4,49 poin.

Berdasarkan hasil analisis dari tes awal sampai tes akhir diperoleh harga thitung sebesar 7,53774 bila dibandingkan dengan ttabel 1,70562 Ini menunjukkan terdapatnya peningkatan yang berarti. Dari analisis data yang dilakukan, ternyata hipotesis alternatif (Ha) yang dikemukakan dalam penelitian ini dapat diterima kebenarannya dengan menunjukan tes awal dan tes akhir berbeda, dengan kata lain terjadi peningkatan antara tes awal dan tes akhir, dan dapat disimpulkan bahwa terdapat pengaruh latihan sprint dan box skip terhadap kemampuan lompat jauh pada atlet pusat pelatihan atletik junior Muaro Jambi.

\section{KESIMPULAN}

Berdasarkan hasil dari analisis data, di peroleh nilai Thitung sebesar 7,53774 dan nilai Ttabel sebesar 1,70562 dengan demikian maka dapat di pahami bahwa penelitian ini ada pengaruh latihan sprint dan box skip terhadap kemampuan lompat jauh pada atlet pusat pelatihan atletik junior Muaro Jambi.

\section{REFERENSI}

Aminudin. 2010. Atletik dan Tekniknya. Quadra. Jakarta. Indonesia

Apriyadi Sompui. 2013. Pengaruh latihan Leg bound dan box skip terhadap kemampuan lompat jauh pada siswa SMP Negeri 21 Banten.

Arikunto. 2006. Prosedur penelitian suatu pendekatan praktek. PT. Rhineka karya. Jakarta

Bellesteros Manuel Jose. 1979. Pedoman Dasar Latiahan Atletik. Spanyol: Manual Didagsion DE Atletismo

Carr . A Gery. 2000. Atletik Untuk Sekolah Dasar. Raja Grapindo Persada. Jakarta.

Chu. Donald. A. 1992. Jumping into plyometric. Champaign. illinois: Human Kinetics pub

Desmi Sartika. 2015. Perbandingan Pengaruh Latihan Box Skip Dan Latihan Incremental Vertical Hop Terhadap Explosive Power Otot Tungkai Pada Siswa Kelas X Putra Jurusan TKBB SMK N 5 Pekanbaru
Dikdik Zafar. Sidik. 2010. Mengajar dan Melatih Atletik.Bandung : Remaja Rosdakarya.

Djumidar Mochamad A. Widya. 2008. belajar berlatih gerak-gerak dasar atletik dalam bermain. : PT Raja Grafindo Persada. Jakarta

Hananto dkk. 2007. Pendidikan jasmani olahraga kesehatan kelas $V$. Yudistira: Jakarta

Harsono. 1988. Coaching dan aspek-aspek psikologis dalam coaching : tambak kusuma. Jakarta

Kosasih. Engkos. 1985. olahraga teknik dan program latihan : Akademika Presindo. Jakarta

Muhajir . 2007. Pendidikan Jasmani Olahraga dan Kesehatan : Erlangga. Jakarta.

Nossek. Yosep. 1982. Teori Latihan Umum.Afrika: LTD Lagos

Nurhasan. 2001. Tes dan pengukuran dalam pendidikan jasmani : prinsip-prinsip dan penerapanya : direktorat jenderal olahraga Jakarta.

Suharno. 1985. Ilmu Kepelatihan Olahraga.: Yayasan STO. Yogyakarta

Sugito. Bambang. W. Ismaryati. 1993. Pendidikan Atletik.. Departemen Pendidikan dan Kebudayaan. Jakarta

Sudjana. 2005. metoda statistika : transito. Bandung

Sutio Kurniawan. 2012. Pengaruh Variasi Latihan Incline Hop Terhadap Kemampuan Lompat Jauh Pada Siswa Kelas V SD Negeri 225/ IX Kota Tanggerang

Tudor Bompa. O. 1994. Power training for sport. Canada. mocaic press.

Winendra. Dkk. 2008. Seri Olahraga Atletik.: Pustaka Insan Madani. Yogyakarta 